\title{
INFORMATION AND DISINFORMATION IN LATE COLONIAL NEW GRANADA*
}

\footnotetext{
I
} n 1814, Alexander von Humboldt, the great traveller and explorer of the Americas, drew attention to an unusual feature of the movement for independence in the Viceroyalty of New Granada: the establishment of printing presses and newspapers followed rather than preceded the outbreak of war. ${ }^{1}$ Humboldt was struck by the contrast New Granada's war of independence offered with the two more famous political revolutions of the age. A great proliferation of printed pamphlets and periodicals had preceded the outbreak of revolution in both the Thirteen Colonies and France. How curious, Humboldt commented, to find the process reversed in Spanish America. Humboldt is not alone in viewing the newspaper as the expected harbinger of change in the age of Atlantic revolution. While the precise role played by the printed word in the French and American revolutions remains a subject of debate, many historians acknowledge the importance of print in creating a climate conducive to revolutionary challenge. ${ }^{2}$ Were newspapers and the press really latecomers to the revolution in the Viceroyalty of New Granada, as Humboldt suggests? What does this tell us about late colonial New Granada? How, in the absence of a

\footnotetext{
* I am grateful to the British Academy for their financial support, which made possible this research, and to the two reviewers for their very helpful comments.

${ }^{1}$ Alexander von Humboldt, Alejandro de Humboldt por tierras de Venezuela (Caracas: Fundación Eugenio Mendoza, 1969), pp. 80-1.

${ }^{2}$ The literature on the subject is extensive. See, for example, Roger Chartier, The Cultural Origins of the French Revolution (Durham: Duke University Press, 1991); Jeremy Popkin, Revolutionary News: The Press in France, 1789-99 (Durham: University of North Carolina Press, 1990); and Robert Darnton Forbidden Best-sellers of Pre-revolutionary France (London: HarperCollins, 1996). For two more traditional analyses of the role of the press in the American Revolution, see Arthur Schlesinger, Prelude to Independence. The Newspaper War on Britain, 1764-1776 (New York: Knopf, 1958); and Bernard Bailyn, The Ideological Origins of the American Revolution (Cambridge: Harvard University Press, 1967).
} 
developed press, did information, revolutionary or otherwise, circulate within the viceroyalty? Moreover, what means were available to either the Spanish crown or the American insurgents to create and manipulate news and opinion? What, indeed, does it mean to speak of the spread of news in a society such as late colonial New Granada? This article seeks to address these questions.

\section{Print AND RUMOR}

We turn first to the way information spread in late colonial and independence-era New Granada. We begin with some comparative comments about the role of print. It has been argued recently that independence-era Mexico was moving from being a fundamentally oral, pre-modern culture to a literate, print-based modern society. According to François-Xavier Guerra, this shift toward modernity was characterized by a dramatic rise in both literacy levels and printing. ${ }^{3}$ In Mexico, the late colonial period saw a great increase in the number of primary schools, and a corresponding rise in the amount of printed material available to the newly formed Mexican readers. This development gave an unprecedented importance to the written word in Mexico's war of independence. Guerra, for example, speaks not only of a "war of words" that mirrored and shaped the armed conflict, but also of the rise of "opinion," as Mexicans of all classes read the hundreds of books, pamphlets and periodicals published each year during the war.

Nothing of the sort occurred in the print backwater that was New Granada. There the printed word did not play a central role in the dissemination of news or opinion through the population at large. To begin with, New Granada's population remained largely illiterate during the years of the war, with limited access to printed material. Figures for school attendance, while only indirect indicators of literacy, do point to a striking difference between Mexico and New Granada. Unlike Mexico, where a large percentage of the eighteenth-century population enjoyed primary education, in New Granada only a minority had access to schooling. José Manuel Restrepo claimed that the shortage of primary schools left at least 80 percent of New Granada's population illiterate. ${ }^{4}$ Even in 1835, a decade after President Francisco de Paula

\footnotetext{
${ }^{3}$ François-Xavier Guerra, Modernidad e independencia. Ensayos sobre las revoluciones hispánicas (Madrid: MAPFRE, 1992), pp. 275-318.

${ }^{4}$ José Manuel Restrepo, Historia de la revolución de Colombia (Medellín: Bolsilibro Bedout, 1974) vol. 1 , pp. $37-45$.
} 
Santander's mammoth effort to alphabetize the population, only a tiny percentage of Colombia's inhabitants attended primary school. According to Frank Safford, in 1835 the percentage of the population attending primary school hovered at about one percent. School attendance in the capital was if anything slightly lower. Using a conservative estimate that children of school-age constituted only one third of the population, Safford's figures suggest that at most three percent of children attended primary school in early republican Colombia. In contrast, historians estimate that in 1820 , roughly half the children in Mexico City attended school..$^{5}$ The small size of Colombia's literate population is further indicated by the fact that even in 1825 the capital had only one small book shop which did poor business. ${ }^{6}$ As Humboldt had lamented, the region apparently contained few "persons who felt the need to read." Of course, Santa Fe de Bogotá also contained a small number of highly educated thinkers, but these individuals, who so impressed the travelling Baron, were in no way representative of the capital's overall population, which was, as we have noted, largely illiterate. The majority of New Granada's population was not receptive to newspapers and pamphlets, political or otherwise, because they were illiterate.

High levels of illiteracy alone do not necessarily prevent the printed word from reaching a wide audience. As historians such as Roger Chartier have shown, writing can be "present at the very heart of an illiterate culture." amplify their message. ${ }^{9}$ It appears that, for these reasons, the printed

\footnotetext{
${ }^{5}$ Frank Safford, The Ideal of the Practical: Colombia's Struggle to Form a Technical Elite (Austin: University of Texas Press, 1976), p. 32. For the striking Mexican figures, see Guerra, Modernidad, p. 279; and Dorothy Tanck Estrada, La educación ilustrada (1786-1836) (Mexico: El Colegio de México, 1977), pp. 196-202. For a very rough indication of the percentage of Neogranadan children of school age, see the census of the Province of Ríohacha from 1825 in the microfilm collection of nineteenth century census material in the Archivo Histórico Nacional de Bogotá, Colombia.

6 William Duane, Viaje a la Gran Colombia en los años 1822-1823, reprinted in David Sowell, Santander y la opinión anglo-americana. Visión de viajeros y periódicos, 1821-1840 (Bogotá: Biblioteca de la Presidencia de la República, 1991), p. 141.

${ }^{7}$ Humboldt, Alejandro de Humboldt, p. 80; and Renan Silva, Prensa y revolución a finales del siglo XVIII. Contribución a un analisis de la formación de la ideología de independencia nacional (Bogotá: Banco de la República, 1989), p. 39.

${ }^{8}$ Roger Chartier, The Cultural Uses of Print in Early Modern France (Princeton: Princeton University Press, 1987), p. 343.

${ }^{9}$ There is surprisingly little evidence that printed works were routinely read aloud to reach larger audiences in New Granada, although they surely were. For a lone example from 1822 , see
} 
page in early modern France had an importance that far outpaced the literacy of the population. Could not the same be true of late colonial New Granada? Certainly we need to look beyond literacy levels alone to determine the impact of the press on the population. However, in so doing we will merely reveal further the gulf that separated New Granada from France, or indeed from Mexico. Print was able to reach a large illiterate audience in seventeenth century France because there was a great deal of it. To cite but one example, within weeks of the surrender of La Rochelle in 1628, several hundred pamphlets, leaflets, and books celebrating the event appeared in Paris alone. ${ }^{10}$ In an environment saturated with print, it is not surprising that the illiterate or semi-illiterate used and appropriated printed texts. As we shall see, the situation in late colonial New Granada was different.

Beyond widespread illiteracy, the number of printing presses itself imposed severe limitations on the reach of printed material. At the start of the war in 1810 , New Granada as a whole had only three poorly-equipped printing workshops: the official "Imprenta Real"; Antonio Nariño's press "La Patriota," both in the capital; and the press of the Consulado de Cartagena. These three printing workshops shared a mere five printing presses, one of which dated all the way back to $1738 .{ }^{11}$ This antique collection constituted New Granada's entire stock of printing presses on the eve of independence (See Table).

Moreover, their geographical concentration obviously restricted access to printing to those in Cartagena and the capital. Thus, at the start of the war of independence, the potential influence of print was limited. Although during the first phase of the war, from 1810 to 1815 , the number of printing presses increased from five to nine, as regional juntas in Popayán, Tunja and Medellín purchased machines, this still

David Bushnell, "The Development of the Press in Great Colombia," Hispanic American Historical Review, 30 (1950), 435.

${ }^{10}$ Christian Jouhaud, "Printing the Event: from La Rochelle to Paris," The Culture of Print: Power and the Uses of Print in Early Modern Europe, Roger Chartier, ed., (Cambridge: Polity Press, 1989), p. 290.

${ }^{11}$ For this and the subsequent discussion of Neogranadan publishing, see Gustavo Otero Múñoz, Historia del Periodismo en Colombia (Bogotá: Editorial Minerva, 1936); José Torre Revello, Los origenes de la imprenta en la América española (Madrid: Francisco Beltrán, 1927); José Torre Revello, Orígenes de la imprenta en España y su desarrollo en América Española (Buenos Aires: Editorial Araujo, 1940); and the many works of José Toribio Medina, particularly Historia de la imprenta en los antiguos dominios españoles de América y Oceanía, 2 vols. (Santiago de Chile, 1958). 


\section{First Printing Presses in New Granada $1738-1820$}

\begin{tabular}{|c|c|}
\hline DATE & 1738 \\
\hline LOCATION & Santa Fe \\
\hline OWNER & Society of Jesus \\
\hline DATE & 1776 \\
\hline LOCATION & Cartagena (soon taken to Santa Fe) \\
\hline OWNER & Antonio Espinosa de los Monteros \\
\hline DATE & 1782 \\
\hline LOCATION & Santa Fe \\
\hline OWNER & Viceroy Manuel Antonio de Flóres \\
\hline DATE & 1793 \\
\hline LOCATION & Santa Fe \\
\hline OWNER & Antonio Nariño (later Nicolás Calvo y Quijano) \\
\hline DATE & 1800 \\
\hline LOCATION & Cartagena \\
\hline OWNER & Consulado de Cartagena \\
\hline DATE & 1813 \\
\hline LOCATION & Cartagena \\
\hline OWNER & Manuel González y Pujol \\
\hline \multicolumn{2}{|c|}{$\begin{array}{l}\text { This press probably did not constitute a new piece of machinery. It was apparently } \\
\text { constructed from parts taken from the Consulado de Cartagena's existing press. }\end{array}$} \\
\hline DATE & 1813 \\
\hline LOCATION & Tunja \\
\hline OWNER & Francisco José de Caldas \\
\hline DATE & 1814 \\
\hline LOCATION & Medellín \\
\hline OWNER & Juan Bautista del Corral* \\
\hline DATE & 1814 \\
\hline LOCATION & Popayán \\
\hline OWNER & Junta Suprema de Popayán \\
\hline DATE & $1816 ?$ \\
\hline LOCATION & Santa Marta \\
\hline OWNER & Colegio Seminario \\
\hline DATE & 1820 \\
\hline LOCATION & Panama \\
\hline OWNER & unknown \\
\hline
\end{tabular}

* Corral's printer was Manuel María Viller-Calderón. I am grateful to the anonymous reviewer for this information.

SOURCES: Gustavo Otero Múñoz, Historia del periodismo en Colombia, Biblioteca Aldeana de Colombia (Bogotá: Editorial Minerva, 1936); José Toribio Medina, La imprenta en Cartagena de Indias (1809-1820), (Santiago de Chile, 1904); José Toribio Medina, Notas bibliográficas sobre la imprenta en Bogotá, 1739-1821 (Santiago de Chile, 1904); José Toribio Medina, La imprenta en algunas ciudades de la América Española, 1754-182.3 (Amsterdam: N. Isracl, 1964); and José Toribio Medina, Historia de la imprenta en los antiguos dominios españoles de América y Oceania, 2 vols. (Santiago de Chile, 1958); José Torre Revello, Los origenes de la imprenta en la América española (Madrid: Francisco Beltrán, 1927); and José Torre Revello, Orígenes de la imprenta en España y su desarrollo en América Española (Buenos Aires: Editorial Araugo, 1940). 
left many regions without any access to print. Even Viceroy Francisco Montalvo had no printing press between 1813 and $1816 .{ }^{12}$ So during the war of independence in New Granada, there were few readers and fewer printing presses. These two factors sharply limited the impact of the printed media.

It is thus not surprising that the Neogranadan wars of independence witnessed no great outpouring of printed material comparable to that allegedly taking place in Mexico. It is for this reason that no great stock of pamphlets and revolutionary tracts from the independence years has been found. This is not to say that the printed word was entirely absent from late colonial New Granada. In particular, the origins of Colombian journalism are to be found in this period. Beginning in 1785, a trickle of periodicals (five, to be precise) began to appear, and after the outbreak of war in 1810 the fragmentation of authority gave rise to a number of new newspapers, as regional juntas sponsored the publication of journals. Approximately 18 new journals were created during the first years of the war, seven outside of the old capital, Santa Fe. However, this significant increase in the number of titles should not obscure the fact that the total number of publications remained very small in absolute terms.

Moreover most were of extremely short duration. At no time before or during the war were more than seven different periodicals being published in the entire viceroyalty. We might compare this with the number of journals published in the United States at roughly the same time. There some 518 different titles were being published simultaneously..$^{13}$ (In other words, the United States had nearly thirty times more newspapers per million inhabitants than New Granada.)

Not surprisingly, most Neogranadan papers appear to have folded for want of readers. For example, the Diario Político de Santafé de Bogotá, New Granada's first explicitly revolutionary paper, was forced to close for lack of readers after its forty-sixth issue. The editors themselves blamed their demise on the "very poor ... sales in this capital and the virtual absence of sales in the provinces." 14 After the outbreak

\footnotetext{
${ }^{12}$ See Francisco Montalvo to Ministry of Grace and Justice, Santa Marta, 22 August 1813, Archivo General de Indias Seville, (henceforth AGI), Audiencia de Santa Fe, legajo 746.

${ }^{13}$ Richard Brown, Knowledge is Power: The Diffusion of Information in Early America, 17001865 (Oxford: Oxford University Press, 1987), p. 218.

${ }^{14}$ Sergio Elias Ortiz and Luis Martínez Delgado, El periodismo en La Nueva Granada, 18101811, Biblioteca Eduardo Santos, vol. 22 (Bogotá: Editorial Kelly, 1960), p. xxxii.
} 
of war in 1810 only official gazettes such as the Gazeta Ministerial de Cundinamarca, which were supported by the Congress or other governmental bodies, survived more than a year. Moreover, the print runs were generally small. The restricted size of the reading public was not the only limit on the number of copies printed; chronic paper shortages alone had already impeded the dissemination of journals prior to the start of the war. ${ }^{15}$ The difficulties of transporting papers beyond the region in which they are printed further reduced sales.

The Patria Boba, from 1810 to 1815, thus did not see the development of a vibrant print culture. Nor did the royalists make greater progress in promoting journalism. During the royalist reconquest of 1816-1819, only two newspapers appear to have been produced regularly in New Granada: the Gaceta de Santafé de Bogotá, and the Boletin del Ejército Expedicionario, augmented by a small stream of gacetas extraordinarias published by both royalists and republicans. The outbreak of the war of independence, in short, neither gave rise to nor was preceded by an autocthonous newspaper culture. It was not until the effective end of the war in 1821 that any real growth occurred in Colombian publishing. After 1820 a number of new printing presses were imported, allowing a corresponding growth in newspaper and pamphlet production. ${ }^{16}$ Thus, home-grown newspapers were not the prime source of information for New Granada's inhabitants during the period in question.

Of course, newspapers produced in New Granada itself were not the only printed source of news to circulate within the viceroyalty. Englishlanguage papers published in the British Caribbean reached New Granada's Caribbean coast, despite periodic efforts by royalist authorities to ban or regulate their sale. Official Spanish papers, most notably the Gaceta de Madrid, were also sold in major cities. Finally, Spanish-language papers published elsewhere in the Americas, as well as those published by dissident Spaniards in Britain, reached a certain

\footnotetext{
${ }^{15}$ For example, see Otero Múñoz, Historia del periodismo, p. 25. See also Silva, Prensa y revolución, for comments about the limited reach of late colonial newspapers.

${ }^{16}$ For the press after 1820, see Bushnell, "The Development of the Press"; and Eduardo Posada-Carbó, "The Role of Newspapers and Leaflets in Electoral Campaigns in Colombia, 1830-1930," presented at the 1995 LASA conference in Washington, D.C. Although this paper does not look explicitly at Venezuela, similar phenomena obtained there. Between 1810 and 1819 , eleven journals were published in Venezuela. Between 1820 and 1830, eighty different titles were published. See Julio Febres Cordero, Historia de la imprenta y del periodismo en Venezuela, 1800-1830 (Caracas: Banco Central de Venezuela, 1974), appendix.
} 
readership. Overall, the demand for foreign newspapers appears to have been small. It was, for example, very unusual for officials or officers, be they royalist or republican, to refer facts gleaned from such sources in their correspondence. Even Bolívar made little use of such newspapers until the $1820 \mathrm{~s} .{ }^{17}$ The printed media were not the prime conveyers of news to most of New Granada's population during the period. For the literate minority, the letter, rather than the printed word, was the principal written source of news. The letter was a vital font of information both for governments and private citizens, not to mention present-day historians. Late colonial New Granada's generally secure (although slow) post allowed letter-writers to send reports and impressions across much of the country. Although the war delayed and disrupted letter delivery, a surprising amount of post continued to circulate during the period from 1810 to $1825 .{ }^{18}$ Letters continued to form the backbone of the Spanish administrative structure, and access to the news contained in official missives was an important prerogative of the privileged. "Reservada," "extraordinaria y muy reservada," administrative officials might write on their correspondence, emphasizing the exclusive nature of the news it contained. Letters not labelled "top secret" might be copied and distributed to other privileged readers. Whether "official" or "personal," letters contained the most disparate types of news. Commercial reports mingled with personal gossip and political commentary. ${ }^{19}$ Absence of letters provoked bitter complaint. "You cannot imagine my concern at receiving no letters from Bogotá," complained Bolívar in 1823. ${ }^{20}$ Viceroy Montalvo devoted entire epistles solely to lamenting the lack of post from Spain. Indeed, printed news of whatever sort might be considered less reliable than a letter from a trusted source. ${ }^{21}$ Letters, then, played a central role in the dissemination of news to the literate population. But was the written

\footnotetext{
${ }^{17}$ Compare the references to newspapers of any sort in volumes 1 and 2 of Vicente Lecuna, Selected Writings of Bolivar (New York: The Colonial Press, 1951).

${ }^{18}$ For the speed of letters shortly after independence, see Charles Stuart Cochrane, Journal of a Residence and Travels in Colombia during the Years 1823 and 1824 (New York: AMS Press, 1971), p. 46. Reported attacks on mail carriers were rare. For one from 1818, see Archivo Central del Cauca, Popayán (Colombia), Independencia JI-15cr, sig. 6099. As a reviewer of this article noted, the collected correspondence of individuals such as Bolívar and Santander itself indicates that letter-writing allowed lengthy epistolary exchanges in which letters were generally received. Missing letters and lack of replies are a source of surprise and comment. I am indebted to the reviewer for this observation.

${ }^{19}$ For a large collection of "personal" letters from 1823, see AHNM, Estado, legajo 6375.

${ }^{20}$ Simón Bolivar to Francisco de Paula Santander, Guayaquil, 29 March 1823, Lecuna, Selected Writings of Bolivar, vol. 2, p. 363.

${ }^{21}$ Many of Francisco Montalvo's letters from 1814 are in AGI, Audiencia de Santa Fe, legajo
} 
word, in whatever form, the only source of news for New Granada's elites? And how did the illiterate majority gather information?

For elites and non-elites alike, the non-written world of conversation and hearsay was a rich source of news and information. Rumor and counter-rumor circulated across large areas via gossip networks and chispería. In 1810, after Viceroy Antonio Amar received reports that suspicious foreigners had been sighted in the eastern plains, rumors about the identity of these men buzzed through the capital. "The uproar and speculation was incredible," José María Caballero recorded in his diary. ${ }^{22}$ Nor did the Atlantic Ocean necessarily impede the spread of gossip. News of relatives in Spain, borne by travellers, might reach even inhabitants of small villages. ${ }^{23}$ The absence of accessible written or printed sources of news was remedied by the active generation of oral reports, spread by both locals and travellers. As an example, we might consider a report that circulated through Cartagena in April $1819 .{ }^{24}$ In that month a cocktail of anti-royalist rumors spread across the city. These rumors combined the usual story that King Ferdinand VII had fled Spain with more elaborate reports of local royalist defeats. In particular, Cartagena's royalist garrison was reputed to be planning a mutiny. These (entirely false) rumors circulated throughout Cartagena via word of mouth. Even Viceroy Juan Sámano, trapped in Cartagena after the Battle of Boyacá, learned of the rumor, when one of his spies was stopped in the street by two news-bearing women. The women, eager for information, begged the spy to tell them whatever he knew about the supposed mutiny; this was the first the spy heard of the rumor. The women had learned of the rumor while on the way home from mass. En route, they had eavesdropped on a group of men discussing the threatened rebellion, and were themselves eager to discuss (and thereby spread) the rumor further. Walking home from mass thus

631, ramo 3. For a comparison of the reliability of the Gaceta de Madrid and a letter from the crown, see the Francisco Montalvo's Pardon, 18 June 1817, AGI, Papeles de Cuba, legajos 717 and 708 .

22 José María Caballero, Diario (Bogotá: Biblioteca de Bogotá, Editorial Villegas, 1990), p. 73.

${ }^{23}$ For good examples from colonial Mexico, see Richard Boyer, The Lives of the Bigamists: Marriage, Family and Community in Colonial Mexico (Austin: University of New Mexico Press, 1995), chapter 5: "The Flow of Information."

${ }^{24}$ Juan Sámano to Gabriel de Torres, Cartagena, 20 March 1819, AGI, Papeles de Cuba, legajo 708. For comparative remarks about the centrality of gossip in spreading news in seventeenth century England, see Richard Cust, "News and Politics in Early Seventeenth-Century England," Past and Present, 112 (1986); and for eighteenth-century France, see Arlette Farge, Fragile Lives, Violence, Power and Solidarity in Eighteenth-Century Paris (Cambridge: Polity Press, 1993), chapter 1 . 
helped one keep abreast of the latest news. (This was presumably why the spy was strolling down the street in the first place). Of course, not only the route to and from mass, but also mass itself might provide occasion for the circulation of the latest rumor. As Bolívar complained, the clergy were all too inclined to spread their views on recent events "in the pulpits of the churches and in the streets." 25 The importance of gossip and hearsay was not limited to the world of the poor or the illiterate. On the contrary, oral communication played a central role in the circulation of news among all classes. Of course, some conversation networks were more socially inclusive than others. The famous tertulias, or salons, of Santa Fe's elite confined their political gossip to a particularly narrow group, but other rumors ranged more widely. Even presidentes gossiped with their staff, and rumors originating in Cartagena's demi-monde might reach the ear of the viceroy. ${ }^{26}$ Political leaders certainly followed oral news avidly. Official reports make frequent allusion to the chispas, "noticias vagas" and "rumores" that sped through communities: "gossip is circulating that Puerto Cabello has surrendered," reported a conscientious Francisco de Paula Santander in 1814. A lack of rumors was annoying: "I have no news of the Congress, ... not even hearsay," Bolívar complained in 1823.27 When a rumor became persistent enough, most officials felt it wise to investigate. The deliberate spreading of false rumors was a military offense, and suspected rumor-mongers (chisperos) were sent to the capital, Santa Fe, for trial.

[Captain] Acero has been imprisoned for having disseminated the news that 5,500 godos [royalist troops] are coming this way. He claims that everyone is saying the same .... Who gave these people permission to spread gossip that disturbs the tranquillity of this province and discourages people?

\footnotetext{
${ }^{25}$ Simón Bolívar to Francisco de Paula Santander, Lima, 11 March 1825, Lecuna, Selected Writings of Bolivar, vol. 2, p. 484. For royalist complaints about the propagandizing efforts of New Granada's clergy, see the letters of José María Barreiro to Juan Sámano, 1819, AGI, Papeles de Cuba, legajo 747.

${ }^{26}$ See, for example, Toribio Montes to Despacho Universal de Indias, Quito, 7 December 1815 , AGI, Audiencia de Quito, legajo 275; and Informant to Juan Sámano, Cartagena, 20 March 1819, AGI, Papeles de Cuba, legajo 708.

${ }^{27}$ Francisco de Paula Santander to Manuel del Castillo, 1814 Santander y los ejércitos patriotas, 1811-1818, vol. 1, Andrés Montaña, ed., (Bogotá: Biblioteca de la Presidencia de la República, 1989), p. 82; and Simón Bolívar to Francisco de Paula Santander, Guayaquil, 29 March 1823, Lecuna, Selected Writings of Bolivar, vol. 2, p. 367. For a useful discussion of the "contagious diffusion" of news and its importance to members of the elite in North America, see Brown, Knowledge is Power, chapter 10.
} 
Santander wrote in $1819 .{ }^{28}$ Both loyalist and republican Government officials took considerable interest in what people said.

The importance of the spoken word is further indicated by the fact that even ostensibly printed sources of news were often launched into the public arena in oral form. Official government publicationsbandos, circulares, etc.-were routinely publicized by town criers, who circulated through the streets declaiming the latest governmental decision, while important decrees were read publicly in the main square. Similarly, news released unofficially via written or printed pasquines undoubtedly circulated in oral form, as individuals discussed the lam'poon's contents. Few of the Comunero rebels who in 1780 had claimed the seditious Real Cédula as their official platform would have read it. Equally few Santafereños would have read the actual pasquines that started rumors that Viceroy Amar was in league with the French which circulated through Santa Fe in 1809.29 Even newspapers sometimes saw their purpose as much to comment on well-known events as to inform their readers of unfamiliar news. The editor of La Constitución Feliz, for example, did not find it necessary to name certain individuals involved in the revolutionary disturbances of July 1810, because their names were "perfectly well known in this city". ${ }^{30}$ In other words, the editor expected that his readers would already be familiar with recent events prior to reading the newspaper. Newspapers were not necessarily a source of news. ${ }^{31}$

\section{Censorship and Disinformation}

Rumors and letters, then, were the principal sources of information available to an inhabitant of New Granada during the years of the war.

\footnotetext{
${ }^{28}$ Francisco de Paula Santander to Comandante del Palmar, 19 January 1819, Santander y los ejércitos patriotas, 1819, vol. 2, Andrés Montaña, ed. (Bogotá: Biblioteca de la Presidencia de la República, 1989), p. 1. See also Diary of the First Battalion of the Regimiento de Infantería de Numancia, Third Division, April 1817, AGI, Papeles de Cuba, legajo 759B; and Francisco de Paula Santander to Simón Bolívar, Santa Fe, 6 November 1819, Cartas Santander-Bolivar, 18131820, vol. 1, Guillermo Hernández de Alba, ed. (Bogotá: Biblioteca de la Presidencia de la República, 1985), pp. 193-4.

${ }^{29}$ Anthony McFarlane, Colombia before Independence. Economy, Society and Politics under Bourbon Rule (Cambridge: University of Cambridge Press, 1993), p. 332. For comparative comments on defamatory posters in eighteenth-century Paris, see Farge, Fragile Lives, pp. 15-16.

${ }^{30}$ La Constitución Felíz, 17 August 1810, number 1, reprinted in Ortiz and Martínez, El periodismo en La Nueva Granada, p. 4.

${ }^{31}$ See Darnton, Forbidden Bestsellers, chapter 7 for comments on the relationship between printed and non-printed sources of news in pre-revolutionary France.
} 
Newspapers and other printed materials played a secondary role. Information, from whatever source, did not flow unimpeded, but was subject to control and alteration. Individuals could not assume that the news they received was accurate. Instead, the reliability of a new report had to be assessed on the basis of its origin and its route to the recipient. News direct from a familiar source was far more creditable than a second-hand report in a foreign paper. ${ }^{32}$ Rumors from an unfamiliar traveller were regarded as preliminary until confirmed by other sources. ${ }^{33}$ There were several reasons for such caution. Firstly, news was often distorted unintentionally as it spread. Obtaining any sort of information from outside the locality was a slow process. New Granada's geography and inadequate road system greatly hampered communication. It could take months for news to reach its intended destination. Information thus travelled slowly, often collecting embellishments along the way. For this reason dramatic reports from other regions were greeted with skepticism. When for example (incorrect) rumors circulated in early 1816 in the capital that the royalist General Pablo Morillo had been captured by Cartagena's insurgents, the artisan-diarist José María Caballero did not feel the need even to explain the reasons for his incredulity. "I don't believe it because I don't believe it," he recorded. ${ }^{34}$ Thus, even news originating from a source all considered creditable might lose its reliability as it passed from person to person. ${ }^{35}$ However, not all pieces of information originated from "reliable" sources. Nor was all distortion unintentional. Rumors did not originate solely from a disinterested desire to share important news. Newspapers were not produced simply to inform the public. The flow of information was also subject to deliberate control and manipulation. We turn now to attempts during the war of independence to direct and shape the spread of news.

The most direct way of controlling information is censorship. Books, newspapers, and even individuals could be banned from entry into New Granada if their presence was felt to be prejudicial. The royalists,

\footnotetext{
${ }^{32}$ See note 21.

${ }^{33}$ See Rebecca Earle, "The Spanish Political Crisis of 1820 and the Loss of New Granada," Colonial Latin America Historical Review, 3 (1994), pp. 260-261, notes 16-18, for the gradual acceptance of a rumor in Cartagena.

${ }^{34}$ Caballero, Diario, p. 200.

${ }^{35}$ See Gabriel de Torres to Gabriel García Vallecilla, Cartagena, 23 March 1820, AGI, Papeles de Cuba, legajo 742 .
} 
indeed both sides, made serious efforts to suppress undesirable news. During the Peninsular War, "seditious papers" which accurately reported Napoleon's successes were banned from circulating in the Americas by the royalists, while pro-constitutional papers were similarly prohibited after 1815 in a futile attempt to hide the deep divisions within Spanish politics. ${ }^{36}$ Given the essentially oral origins of much news, it should not appear surprising that, on occasion, individuals themselves were incarcerated to prevent them from spreading unwelcome news, in an extreme form of censorship. Men who had witnessed the re-introduction of the Spanish Constitution of 1812 in Cuba were locked up by New Granada's viceroy in 1820 in an effort to prevent the news from spreading. ${ }^{37}$ One might also consider as censorship the efforts of both royalists and insurgents to prevent the spread of information by physically blocking roads and seizing mail deliveries. This occurred, for example, after the decisive Battle of Pichincha in 1822, which ended Spanish control of Quito, leaving royalists north of Quito vulnerable to republican attack. The royalists, however, controlled crucial roads between Quito and the viceregal capital, and so were able to prevent news of the battle from reaching Bolívar in Santa Fe. ${ }^{38}$ Censorship was thus regularly used during the years of the war. But how effective was it? In theory, the Spanish monarchy had long controlled the entry of absolutely everything into its American colonies, but it hardly needs stressing that the monarchy's practical ability to do this fell far short of total control. Banned books and papers continued to circulate during the war as they had in previous decades; indeed, Cartagena's royalist governor conceded that prohibited English newspapers circulated unimpeded after $1818 .{ }^{39}$ Moreover, it has often been argued that censorship alone is, if anything, counter-productive. The mere suppression of news leaves a vacuum soon filled by rumor and speculation, which are much more difficult to control. Censorship, in other words, is more effective when it is accompanied by active propaganda to fill the void left by suppression. The most effective com-

\footnotetext{
${ }^{36}$ See, for example, Georges Lomné, "Las ciudades de la Nueva Granada: Teatros y objetos de los conflictos de la memoria política (1810-1830)," unpublished conference paper, "Les Enjeux de la Mémoire" Colloquium (Paris, 1992), p. 5.

${ }^{37}$ Earle, "The Spanish Political Crisis, p. 261.

${ }^{3 *}$ See Simón Bolívar to José de San Martín, 22 June 1822, Lecuna, Selected Writings of Bolivar, vol. 1, p. 52 .

${ }^{39}$ Juan Sámano to Gabriel de Torres, Cartagena, 20 March 1819 and 9 June 1819; and Gabriel de Torres to Juan Sámano, Cartagena, 30 September 1818 and 9 May 1819; all in AGI, Papeles de Cuba, legajo 708.
} 
bination is, as one historian put it, to "censor and sponsor." ${ }^{40}$ Let us now turn to the use of propaganda during the war. We will not dwell on the use of overt propaganda in the form of official gazettes, etc., because we have already discussed the role of such official sources in spreading information. We will, rather, consider the more interesting subject of covert propaganda, or disinformation. The very difficulty of obtaining reliable information made it tempting for propagandists on both sides to circulate deliberately concocted stories. The time that it took to verify news reports provided a certain breathing-space for propaganda to flourish. Wartime disinformation was sanctioned at the highest levels, and not only in New Granada; Viceroy Félix María Calleja of Mexico admitted to publishing falsified accounts of battles in order to bolster royalist opinion. From New Granada, Simón Bolívar provided republican agents in London with false reports of royalist defeats, which were presumably publicized to discourage royalist sympathizers in England. ${ }^{41}$ While both royalists and republicans made use of written disinformation of this sort, it seems that much, if not most, wartime propaganda was spread orally, via deliberately-started rumors. This should not be surprising given that, as we have seen, oral communication played a central role in the spread of news. New Granada had a small literate population and a small number of printing presses, both of which made the use of written or printed propaganda problematic.

New Granada was not unique in its use of oral propaganda during this period. Even in the comparatively literate Britain, most antiNapoleonic propaganda apparently took an oral form. Nor did Napoleon, generally regarded as an early master of modern propaganda, ignore oral disinformation. Napoleon regularly instructed his agents and ambassadors to spread favorable rumors. ${ }^{42}$ The important role played by oral disinformation in New Granada was thus not solely a consequence of the shortage of printing presses.

\footnotetext{
${ }^{40}$ Joseph Klaits, Printed Propaganda under Louis XIV. Absolute Monarchy and Public Opinion (Princeton: Princeton University Press, 1976), p. 8.

${ }^{41}$ Timothy Anna, "The Last Viceroys of New Spain and Peru: an Appraisal," American Historical Review, 81 (1976), 51; and Simón Bolívar to Luis López Méndez, Angostura, 12 June 1818, Escritos del Libertador, vol. 12 (Caracas: Sociedad Bolivariana de Venezuela, 1973), pp. 293-297. See also Gerhard Masur, Simón Bolívar (Albuquerque: University of New Mexico Press, 1948), p. 455.

${ }^{42}$ Robert Hole, "British Counter-Revolutionary Popular Propaganda in the 1790s," Britain and Revolutionary France: Conflict, Subversion and Propaganda, Colin Jones, ed., Exeter Studies in History No. 5 (Exeter: Exeter University Press, 1983), p. 53; and Robert Holtman, Napoleonic Propaganda (Baton Rouge: Louisiana State University Press, 1950), pp. 111-119.
} 
We will now examine these propagandistic rumors a bit more closely. Tracing rumors is, of course, difficult. Sometimes only their skeletons remain, as is the case with the "insidious rumors" spread by royalist agents in the Antilles in 1818. Whatever the content of these rumors, they managed to keep in port five ships laden with arms and munitions for the republicans, which never reached Bolívar. ${ }^{43}$ More rarely, the rumor leaves a definite imprint. "Have it voiced that I am coming your way. Keep saying that you expect me, so that the enemy will not know which way I am headed," Bolívar instructed Páez in $1818 .{ }^{44}$ Disinformation of this sort were used throughout the war of , independence, beginning with the deliberately started rumor that a Spaniard had insulted New Granada's creoles, which led to the initial break with Spain in July $1810 .{ }^{45}$ As one might expect, the most successful disinformation confined itself merely to confirming or augmenting existing rumors. As Aldous Huxley noted, propaganda spreads most effectively when it "canalises an already existing stream." 46 Thus, during the Peninsular War, republican agents in New Granada circulated deliberately-amplified stories of Spanish defeats and French victories to discourage would-be royalists. ${ }^{47}$ The most striking example of this sort of canalising rumor concerns the capture of the Spanish monarchs by Napoleon. The imprisonment of Ferdinand VII inspired a large body of false rumors in subsequent years. Over and over again doubts were spread about whether Ferdinand really had returned to the throne, or whether he had been forced once again to abdicate. Already in 1816, reported the Canon of Santa Fe's Cathedral, Andrés María Rosillo, "in many parts the opinion has formed that your majesty has not had his throne restored to him." ${ }^{48}$ Four years later, such rumors were still going strong. In 1820, republicans reportedly gained control of the coastal town of Ríohacha by

\footnotetext{
${ }^{43}$ Simón Bolívar to Luis López Méndez, Angostura, 12 June 1818, Lecuna, Selected Writings of Bolívar, vol. 1, p. 155.

${ }^{44}$ Simón Bolívar to José Antonio Páez, Angostura, 29 September 1818, Lecuna, Selected Writings of Bolivar, vol. 1, p. 168.

${ }^{45}$ For a discussion of the florero incident, see Indalecio Liévano Aguirre, Los grandes conflictos sociales y económicos de nuestra historia, vol. 2 (Bogotá: Tercer Mundo, 1985), chapter 20.

${ }^{46}$ John Mackenzie, ed., Imperialism and Popular Culture (Manchester: Manchester University Press, 1986) p. 113

${ }^{47}$ Sergio Elías Ortiz, Génesis de la revolución del 20 de julio de 1810, Biblioteca Eduardo Santos, vol. 19 (Bogotá: Editorial Kelly, 1960) p. 165.

${ }^{48}$ Andrés María Rosillo to Secretary of Grace and Justice, 13 July 1818, AGI, Estado, legajo 57, doc. 36. See also Juan Sámano (?) to Ignacio Valencia, Popayán, 30 April 1816, Biblioteca de la Real Academia de Historia, Madrid, Sig. 9/7665 (leg. 22), fol. 8; and Melchor Aymerich to Minister of Grace and Justice, Quito, 22 November 1819, AGI, Audiencia de Quito, legajo 261.
} 
convincing the population that Ferdinand had been imprisoned in London following an uprising in Spain. ${ }^{49}$ On occasion, efforts were even made to convince the public, not that Ferdinand had been captured, but that he was indeed dead; the pro-independence Marquesa de Maenza reportedly prayed aloud for the soul of Ferdinand every day in the church of Santa Catalina in Quito, "in order to convince the public that the king was already dead." 50 The behavior of the Marquesa highlights the way in which propaganda tapped into "nonpolitical" communication networks. Praying aloud in church was evidently an effective way of launching a rumor into the public arena. This link between ordinary information-sharing and deliberate propaganda can be seen particularly clearly in the case of one rumor to which we have already referred. We earlier considered the rumor that spread through Cartagena in April 1819 to the effect that Ferdinand VII had been expelled from Spain and that the royalist garrison was plotting to rebel. The rumor was spread across the city by groups of gossiping men and women, some of whom became greatly alarmed by the reports. Despite the fact that the rumor thus spread naturally through the usual communication networks, this particular rumor had in fact been started deliberately. It apparently originated in what the royalist viceroy referred to as a shadowy republican cell (described by its members as a respectable tertulia). It was then spread across the city by algunas mujercillas of dubious morals who supported independence. ${ }^{51}$ Supporters of independence thus tapped into existing gossipnetworks, thereby spreading disinformation in the way likely to reach most people.

This is an opportune moment to discuss a further aspect of the spread of rumor. This concerns the participation of women in rumor networks. Much of the historiography on rumor and gossip has focused on whether gossiping is a particularly female activity, and on the role rumor-spreading and its punishment has played in women's lives. ${ }^{52}$

\footnotetext{
${ }^{49}$ Jacinto Amaya and Juan Camaleta to Pedro Ruíz de Porras (?), Molino, 15 April 1820, AGI, Papeles de Cuba, legajo 745 .

${ }^{50}$ Historia de la rebelión de América, by Pedro Pérez Múñoz, Quito, 6 May 1815, letter 29, AGI, Diversos, legajo 42.

${ }^{51}$ Juan Sámano to Gabriel de Torres, Cartagena, 20 March 1819, AGI, Papeles de Cuba, legajo 708.

${ }^{52}$ For several rather different studies of gossip which focus on women, see, for example, Steve Hindle, "The Shaming of Margaret Knowsley: Gossip, Gender and the Experience of Authority in Early Modern England," Continuity and Change, vol. 9:3 (1994); Mary Beth Norton, "Gender and Defamation in Seventeenth-Century Maryland," William and Mary Quarterley, vol. 44
} 
Was rumor-spreading in independence-era New Granada a predominately female undertaking? There is little to suggest that political rumors were spread primarily by women. On the contrary, there is a great deal of evidence that many propagandistic "rumors" had their origin, not in some sub-political female realm, but rather in the world of elite politicians. Figures such as Bolívar themselves deliberately started political rumors. Moreover, as we have seen, oral informationsharing, political or otherwise, was neither a specifically female activity, nor was it women's unique point of entry into political life. The ample literature on popular rebellion alone demonstrates the latter point..$^{53}$

\section{CONCLUSIONS}

We have seen that in late colonial and independence-era New Granada it was the spoken rather than the written word that predominated as a propagandistic tool. That much of the propaganda was oral, rather than written, reflects the embryonic state of printing during the period. What, however, does this say about the nature of political space in late colonial and independence-era New Granada? Certainly we see little evidence of an emergent public sphere of the sort described by Jürgen Habermas, who famously argued that bourgeois public space arose out of the fruitful intersection of the coffee house, the journal, and the exhibition. ${ }^{54}$ Lacking all three in any quantity, late colonial New Granada appears to have none of the characteristics of incipient modernity that historians such as Guerra ascribe to late colonial Mexico. The revolutionary ideas that spread through New Granada's political elite may have been shaped in part by the reading of French texts, but the printing press itself was not a key ingredient in the outbreak of war with Spain. Opinion was not roused by revolutionary pamphlets and the radical press.

Yet neither was New Granada a predominantly oral society, in the sense of lacking a dominant written culture. Colonial society in New

(1987); and Melanie Tebbutt, Women's Talk? A Social History of Gossip in Working-Class Neighbourhoods, 1880-1960 (Aldershot: Scolar Press, 1995).

${ }^{53}$ See, for example, Margarita Garrido, "La política local en la Nueva Granada, 1750-1810," Anuario Colombiano de Historia y de la Cultura, vol. 5 (1987); and Anthony McFarlane, "Civil Disorders and Popular Protests in Late Colonial New Granada," Hispanic American Historical Review, 64 (1984).

${ }^{54}$ Jürgen Habermas, The Structural Transformation of the Public Sphere. an Enquiry into a Category of Bourgeois Society (Cambridge: Polity Press, 1994). 
Granada, as elsewhere in Spanish America, was characterized by what Martin Lienhard has called the "fetishisation of writing." Neogranadan society privileged the written word, while nonetheless having relatively little of it. Writing (and reading) had been emblems of power from the earliest days of the conquest, and the viceroyalty's inhabitants acknowledged the special authority of the written word every time they petitioned local officials, or sent the crown a Relación de Mérito. ${ }^{55}$ Moreover, the absence of printed news and propaganda does not mean that New Granada's population remained aloof and uninterested in the developing crisis with Spain. The constant circulation of political gossip and rumour is in itself an indication of political engagement by New Granada's inhabitants with their ancien regime society. ${ }^{56}$ Nor does the relative lack of print mean that propaganda played no role in the war. As we have seen, propaganda and disinformation functioned most effectively on the sub-printed level, via rumors. Rumor, as a semi-clandestine form of communication, has always been potentially political or subversive.$^{57}$ In New Granada, rumor's political potentiality made it the most effective form of propaganda, as it differed least from ordinary means of communication and informationsharing.

The University of Warwick

Rebecca Earle Coventry, England

\footnotetext{
${ }^{55}$ See Martin Lienhard, La voz y su huella: escritura y conflicto étnico-cultural en América Latina, 1492-1988 (Lima: Editorial Horizonte, 1992); and Angel Rama, La ciudad letrada (Hanover, NH: Ediciones del Norte, 1984).

${ }^{56}$ For suggestive comments, see Arlette Farge, Subversive Words. Public Opinion in Eighteenth Century France (Cambridge: Polity Press, 1994).

${ }^{57}$ See, for example, Dagmar Freist, "The King's Crown is the Whore of Babylon: Politics, Gender and Communication in Mid-Seventeenth-Century England," Gender and History, 7 (1995).
} 